\section{EBHRM 9,1}

Received 17 January 2020 Revised 5 July 2020 18 September 2020 Accepted 4 October 2020

\section{Servant leadership and followers' creativity: does climate for creativity matter?}

\author{
Mohammed Aboramadan \\ Department of Economics, Management and Statistics, University of Milan-Bicocca, \\ Milan, Italy
}

\begin{abstract}
Purpose - This research proposes, building on social exchange theory and the componential theory of creativity, a model of servant leadership to investigate its effect on followers' creativity through the intervening mechanism of climate for creativity in the hospitality industry, operating in a non-Western context.

Design/methodology/approach - The study predicted that climate for creativity will play a significant intervening role in the servant leadership-creativity relationship. The study's data were collected from 232 employees working in 70 Palestinian hotels. Data were analyzed using structural equation modeling (SEM) analyses along with techniques used to reduce common method bias.

Findings - The results revealed the significance of climate for creativity as a partial mediator in the relationship between servant leadership and followers' creativity.

Practical implications - The results might be useful for hotel managers in the context of utilizing servant leadership roles for fostering a creative climate. They might, therefore, consider placing servant leaders as a recruitment agenda priority.

Originality/value - This research is novel in three ways. First, its aim is to enrich the empirical literature on servant leadership, which is still in a maturity stage. Second, even with the research studies that are available, limited analysis is found on how servant leadership can stimulate employees' behaviors in the hospitality industry. Third, the study has been conducted in a non-Western context, in contrast to most servant leadership research studies being carried out in Western countries.
\end{abstract}

Keywords Creativity, Climate for creativity, Servant leadership, Hotels

Paper type Research paper

\section{Introduction}

Due to its strong ties with organizational creativity, competitive advantage, effectiveness and also survival (Lee et al., 2019; Zhou and Shalley, 2003), employees' creativity is considered to be the most essential economic asset (Agars et al., 2012). Research suggests that creativity is driven by intrinsic motivation because motivation enhances cognitive versatility, endurance and curiosity (Fischer et al, 2019; Shalley et al., 2004). Leaders can encourage employees' creativity by stimulating their intrinsic motivation, by providing the required resources and by creating working conditions that foster objectives attainment and job autonomy (Minh-Duc and HuuLam, 2019; Shalley and Gilson, 2004; Thao and Kang, 2018; Yang et al., 2017). Servant leadership is one particular form of leadership style that may produce such positive outcomes. The premise of servant leadership is that servant leaders who are able to concentrate less on fulfilling their



(C) Mohammed Aboramadan. Published by Emerald Publishing Limited. This article is published under the Creative Commons Attribution (CC BY 4.0) licence. Anyone may reproduce, distribute, translate and create derivative works of this article (for both commercial and non-commercial purposes), subject to full attribution to the original publication and authors. The full terms of this licence may be seen at http:// creativecommons.org/licences/by/4.0/legalcode

The author declares that this study has not received any funding and it is not part of a funded Evidence-based HRM: a Global Forum for Empirical Scholarship Vol. 9 No. 1, 2021 pp. 78-94

Emerald Publishing Limited

2049-3983
DOI 10.1108/EBHRM-01-2020-0012 project on servant leadership, climate for creativity, innovative behaviors, management innovation and followers' creativity in the hospitality industry in Palestine.

Conflict of interest: The author declares no conflict of interests in this study. 
personal needs and more on meeting their followers' needs and goals are the ones able to better inspire them (Kaya and Karatepe, 2020; Greenleaf, 1970). In general, servant leaders adopt a unique leadership type (Russell and Stone, 2002; Williams et al., 2017) and are distinguished by human-centered, selfless and altruistic behavior (Eva et al., 2019; Avolio et al., 2009).

Research suggests that servant leaders' qualities are effective in enhancing both organizational performance and individual outcomes (Bavik, 2020; Greenleaf, 1970; Langhof and Güldenberg, 2020). Moreover, the leadership literature suggests that the presence of servant leaders brings advantages to the workplace that include higher satisfaction, dedication, involvement and high follower performance (Liden et al., 2008; Neubert et al., 2008). In the same vein, empirical evidence demonstrates that servant leadership exerts a positive effect on followers' organizational citizenship behavior (OCB) (Bavik et al., 2017), performance (Van Dierendonck, 2011), social capital accumulation (Zoghbi-Manrique-deLara and Ruiz-Palomino, 2019), organizational commitment (Ling et al., 2017), work-life balances (Tang et al., 2016) and creativity (Thao et al., 2018).

Lately, a limited number of empirical endeavors went into investigating the servant leadership-creativity relationship in several contexts. For instance, empirical evidence from a range of sources suggests that servant leadership exerts a positive effect on employees' creativity (i.e. Neubert et al., 2008; Yang et al., 2017; Neubert et al., 2016; Williams et al., 2017; Yoshida et al.,2014; Liden et al., 2015; Liden et al., 2014). These studies have suggested that the servant leadership-creativity relationship is mediated by several factors, including promotion focus and job satisfaction, creative self-efficacy and team efficacy, workplace spirituality, leader identification, team potency and serving culture.

Although these studies demonstrate a significant relationship between servant leadership and followers' creativity, a dearth of studies remains on the underlining mechanisms through which servant leaders' behaviors impact follower's creativity (Hunter et al., 2013). This suggests that further analysis of the underlining mechanisms of this relationship would be both ideal and significant. In this paper, the aim is to unlock the servant leadership-creativity relationship by closely examining the role of climate for creativity as a mediating factor. The role of climate for creativity has been highlighted as an antecedent to creativity and innovation (Amabile and Gryskiewicz, 1989; Anderson et al., 2004; Hassi, 2019; Yeh-Yun Lin and Liu, 2012). The importance of climate for creativity stems from the assumption that organizational resources such as systems, culture and climate may lead to creative situations and stimulate employees to display creative behaviors (Kim and Yoon, 2015; Woodman et al.,1993). In a situation where climate provides sufficient resources, support and rewards for creative thoughts and behaviors, employees are more likely to demonstrate high levels of creative behaviors. However, despite the significance of organizational climate in stimulating creative behaviors, there is still an extensive range of issues left unanswered among which is the question of whether climate for creativity plays a significant role in the servant leadership and followers' creativity dynamic. Moreover, a recent literature review by Eva et al. (2019) added that servant leadership research is in its infancy stages and more research is needed. Another literature review paper on servant leadership outcomes and antecedents by Langhof and Güldenberg (2020) highlighted the need to enrich servant leadership literature through more empirical studies. More specifically, Bavik (2020) in his systematic literature review on servant leadership in hospitality research argued that it is important to understand the unique value of servant leadership in the hospitality context. Furthermore, while servant leadership is significant, there are still few studies on the subject in the hospitality business (Wu et al., 2013). Little work existed on how servant leaders affect the performance and behaviors of hotel employees (Ling et al., 2016). On another note, Liden et al. (2014) stressed on the importance of testing the underlining mechanisms in the relationships between servant leadership and its consequences. Further, Karatepe et al. (2019) mentioned that there is limited number of empirical endeavors which investigate the mediating mechanisms through which servant leadership affect several outcomes. 


\section{EBHRM} 9,1

Given the previous discussion and response to these scholarly calls, this research aims to investigate the impact of servant leadership on followers' creativity through the mediating role of climate for creativity. In general, no previous research has investigated the climate for creativity in the context of the servant leadership-creativity relationship. The study relies on data from a Middle Eastern hotel industry, focusing on the task of enriching servant leadership literature in a non-Western context considering that the majority of servant leadership studies have been based in Western settings (Parris and Peachey, 2013).

\section{Theory and hypotheses development}

Servant leadership and followers' creativity

Servant leaders are people-focused leaders whose activities prioritize emphasizing followers' interests rather than any competing interests (Hoch et al., 2018). Servant leaders have a passion for good deeds within the community and are inspired by them (Graham, 1991; Liden et al., 2015). Hence, their selfless emphasis, relentless engagement in followers' growth and complete confidence in followers all combine to make them great resources for organizational advancement within each firm (Stone et al., 2004; Van Dierendonck, 2011). Furthermore, servant leadership has a moral component (Hoch et al., 2018), which demands fair and ethical treatment from all servant leaders in respect to their followers (Graham, 1991). In comparison with other leadership theories, such as transformational leadership, the main difference here is the focus on followers' interests. More specifically, servant leadership being people-oriented aims to safeguard these interests, in contrast with transformational leaders who are organizations-oriented (Stone et al., 2004).

Given its widely recognized role as an innovation prerequisite, creativity has drawn attention far and wide and is considered to be of great significance in behavioral research (Amabile et al., 1996; Amabile, 1988; Thao and Krang, 2018). In particular, scholars have intensively studied employees' creativity because it has been identified as positively linked to organizational innovation, organizational competitiveness and organizational survival (Amabile, 1988; Lee et al., 2019; Oldham and Cummings, 1996; Woodman et al., 1993). The current research study indicates that the social contexts present within an organization are critical to fostering creativity, particularly in terms of effective leadership types that include servant leadership (Amabile and Khaire, 2008; Carmeli et al., 2013; Yoshida et al., 2014).

Empirical studies have shown that servant leadership is positively associated with individual outcomes, for example, related to voice behavior (Lapointe and Vandenberghe, 2018), work engagement (Ling et al., 2017), OCB and thriving at work (Walumbwa et al., 2010, 2018) and performance (Chiniara and Bentein, 2016). However, although researchers have sought to investigate the possible links between servant leadership and followers' creativity, there is still no consensus on how servant leadership actually affects creativity (Newman et al., 2017).

The researcher predicts that servant leaders' behaviors significantly affect followers' creative behaviors. First, servant leaders support and encourage subordinates by delegating them, fulfilling their needs and maximizing their full efforts. As a result, servant leaders contribute to improving followers' motivations for engaging in creative actions (Liden et al., 2015). Second, servant leaders show explicit concern for the interests and needs of their followers instead of their own (Eva et al., 2019; Huning et al., 2020). Therefore, they succeed in creating an atmosphere that is characterized by mutual trust and safety (Yoshida et al., 2014). Third, followers who perceive their leaders as servants are more likely to share and care for each other through a mutual support exchange, thereby strengthening their emotional security (Liden et al., 2015). As a consequence, the risk of seeking creative methods for problem-solving would, therefore, be minimized, which is salutary for fostering the creativity of followers (Liden et al., 2014). Fourth, the relationship between servant leaders and follower's creativity can be explained by social exchange theory (Cropanzano and Mitchell, 2005), which elucidates how followers exchange leaders' behaviors and resources through the concept of reciprocity. According to this theory, 
servant leadership is, therefore, supposed to positively impact followers' creativity, as followers are more likely to reciprocate the positive behaviors of servant leaders with more creative behaviors. Empirically, few studies have examined the relationship between servant leadership and its impact on followers' creativity (i.e. Liden et al., 2014; Williams et al., 2017; Yoshida et al., 2014). Given this discussion, the following hypothesis can be posited:

Servant
leadership and
followers'
creativity

\section{Servant leadership and climate for creativity}

The collective attitude of a workplace toward an organization is called an "organizational climate" (Ko and Kang, 2019; Burton et al., 2004). This organizational climate evolves through social experiences in the organization and impacts employees' behaviors (Manning et al., 2005). A climate for creativity, in particular, is regarded as a perception that encourages new knowledge and practices as well as processes, procedures and actions (Van der Vegt et al., 2005). This includes the management encouraging followers to generate novel solutions and to take risks without being concerned about prejudice (Choi et al., 2013). On the same line of inquiry, Kim and Yoon (2015) highlighted that a climate for creativity is characterized by the availability of resources dedicated to innovation, flexibility, reward systems and recognition.

According to Cloete (2011), the presence of the leader plays a significant role in shaping the organizational climate. More specifically, if there are effective leaders within the organization, a more competitive, more productive and more responsive an organization will be. This is because the climate has a top-down structure through which the leader influences the followers and the whole organization. According to Eustace and Martins (2014), leadership significantly impacts organizational climate. More specifically, transformational leadership has been identified as significant in influencing a creative organizational climate that fosters followers' creative behaviors (Mohamed, 2016). Quality servant leaders can support a learning-based environment that is characterized by tolerance, humility and trust, which in turn foster creativity and innovation (Van Dierendonck and Rook, 2010). Given these arguments, the following hypothesis can be formulated:

\section{H2. Servant leadership positively impacts climate for creativity.}

\section{Climate for creativity and followers' creativity}

In recent years, researchers have made substantial progress in recognizing factors that can foster followers' creativity to benefit organizations, likely being motivated by organizational imperatives for creativity and innovation (Amabile and Mueller, 2008). Indeed, studies have revealed that personal (Feist, 1998) and environmental factors such as organizational support (West et al., 2003) in particular are of great importance. Although the mainstream research' results indicate that the work environment plays an important role in creativity (Oldham and Cummings, 1996; Woodman et al., 1993), several scholars have highlighted the role of climate (Ekvall, 1996; Tesluk et al., 1997; Anderson and West, 1998; West and Sacramento, 2012). For instance, Ensor et al. (2006) found that an absence of organizational barriers enhances creativity among employees. Moreover, the availability of organizational support, when fulfilled by the necessary facilities and resources, also makes positive contributions in this context (Weeks, 2008; Hamel and Valikangas, 2003). Additionally, Porzse et al. (2012) recognized organizational climate as playing a major role in enhancing innovation. In specific, the relationship between climate for creativity and followers' creativity can be explained by the componential theory of creativity (Amabile, 1997). According to this theory, there are social and psychological components which are needed to encourage an individual to generate creative work. In addition to intrinsic motivation and creativity-related processes, the theory highlights that the component of the work environment is essential to stimulate 
EBHRM 9,1

\section{2}

\section{Climate for creativity as a mediator}

Building on what has been discussed before that servant leadership positively impacts climate for creativity and climate for creativity impacts followers' creativity, it can be assumed that climate for creativity can play a mediating role in the aforesaid relationship. Remarkably, employees working in a working environment which needs nonclassical tasks and challenges are in need of learning opportunities, personal growth, rewards and support. The latter can be achieved in a situation where climate for creativity is acknowledged. Empirically, several studies have investigated the mediating role of organizational climate in leadership research. First, Hassi (2019) found that the relationship between empowering leadership and management innovation is mediated by climate for creativity. Hosseini et al. (2003) found that the link between organizational resources and innovation is not straightforward and it is mediated by climate for innovation, while Paulsen et al. (2013) found that organizational perceived support mediated the transformational leadership-innovation relationship. Finally, Sethibe and Steyn (2018) demonstrated that the relationship between leadership (transformational-transactional) and innovative behavior is mediated by organizational climate. Based on that, the following hypothesis can be formulated:

H4. Climate for creativity mediates the relationship between servant leadership and followers' creativity.

\section{Methods}

\section{The research model}

The research study investigates a model of the effects of servant leadership on followers' creativity in the hospitality industry, where, as shown in Figure 1, climate for creativity serves as a mediating mechanism.

\section{Sampling and procedures}

A questionnaire was distributed to employees working in 70 Palestinian hotels. The researchers contacted the hotel administrators via phone and described the main goals of the

Figure 1.

The research model

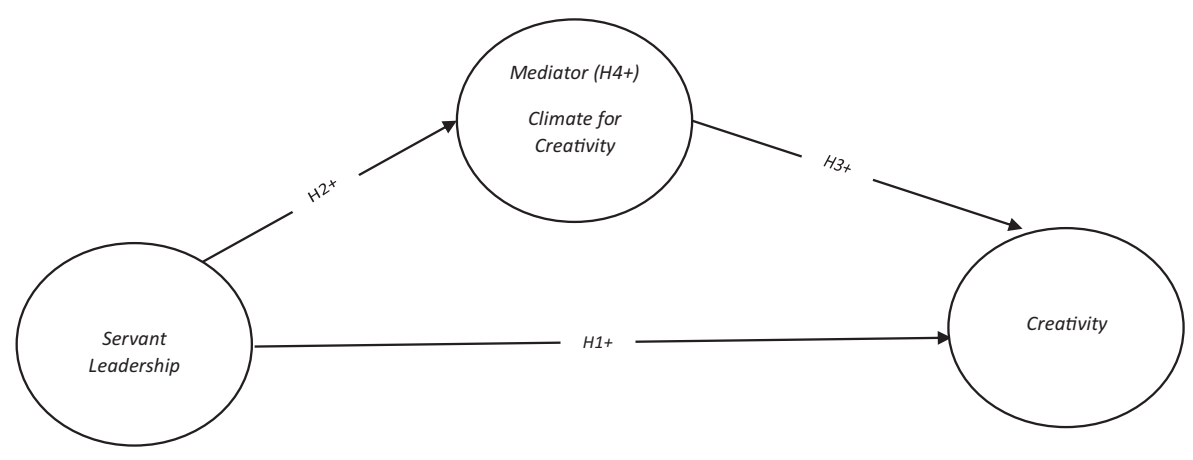


study. The hotel administrators then gave permission for the study to be conducted and provided the researchers with access to distribute the questionnaire to the hotel employees. The researchers distributed 280 questionnaires and received back 235, of which three cases were discarded due to missing data and 232 questionnaires were confirmed as useable for statistical purposes, which indicated a response rate of $82.86 \%$. Respondents were assured that their information will not be shared and remain confidential. A drop-off and pick-up method was used as a distribution method and the questionnaire was translated from English to Arabic following the method of Brislin (1986). Questionnaire items were formatted on a seven-point Likert scale with 1 indicating absolute disagreement and 7 indicating absolute agreement. Of the respondents, $62.1 \%$ were male, $87.4 \%$ were aged more than 27 years, $95.8 \%$ had a university education and $36.3 \%$ had more than 10 years of organizational experience. The respondents were occupying positions in the first-line administration $(9.05 \%)$, reception $(7.76 \%)$, room service $(24.14 \%)$ and the restaurants $(59.05 \%)$.

\section{Instrumentalization}

Servant leadership. This was measured using the seven-item scale developed by Liden et al. (2015). A sample item was, "My leader puts my best interests ahead of his/her own." The internal consistency value for this construct was 0.928 .

Climate for creativity. This construct was measured using the five-item scale developed by Kim and Yoon (2015). A sample item was, "The reward system here encourages employees' creative idea development." The internal consistency value for this construct was 0.936 .

Creativity. This was measured using the nine-item scale developed by Tierney et al. (1999). A sample item was, "I take risks in terms of producing new ideas in doing my job." The internal consistency value for this construct was 0.967 .

Control variables. Following previous field research (Tierney et al., 1999; Williams et al., 2017; Zhang and Bartol, 2010), gender, education, age and organizational experience were controlled for their effects.

\section{The statistical analysis strategy}

SPSS 22 and AMOS 22 were used in this study to test the hypotheses. This was conducted by examining both the measurement and structural models and carried out using the maximum likelihood estimation (Anderson and Gerbing, 1988). For the mediation analysis, unlike the traditional techniques to test mediation effects, the 5,000 bootstrapping method was utilized (Preacher and Hayes, 2008) via AMOS 22. To check for the data's normality, the Shapiro-Wilk test was applied, with the findings revealing that $p$-values were greater than 0.05 - suggesting normally distributed data.

\section{Assessment of the common method bias and construct validity and reliability}

As the study's data were collected from one source, some recommendations suggested by Podsakoff et al. (2003) were followed to minimize the common method variance. First, during the questionnaire distribution, participants were asked to complete the questionnaire with honesty (Conway and Lance, 2010). Second, all the questionnaire items were revised and pretested in a pilot study to avoid ambiguity among the participants (Churchill and Iacobacci, 2002). Third, all the questionnaire items were borrowed from previously validated scales published in top field journals. Fourth, Harman's single-factor analysis was utilized to examine the method bias in the data. The findings of Harman's single-factor test produced three factors that did not load into a single factor, while the single factor does not explain most of the variance $(44.4 \%$ ) which is below the cutting edge of $50 \%$, as suggested by Podsakoff et al. (2003). 
EBHRM

9,1

\section{4}

A confirmatory factor analysis was conducted to check for the data fit and the distinctness of the research variables. As shown in Table 1, the default hypothesized study model showed a good fit with all the fit indices $\chi^{2}=512.236 ; \mathrm{df}=262 ; p=0.000 ; \mathrm{CFI}=50.957$, TLI $=0.950$; $\mathrm{SRMR}=0.060$; RMSEA $=0.064$ ). Moreover, four alternate models were built into the chisquare model comparison (Bentler and Bonett, 1980), and the results suggested that the default model was superior to the competing models.

The results presented in Table 2 indicated that the standardized loadings for the items were higher than 0.60. Moreover, the average variance extracted (AVE) and the composite reliability (CR) were both calculated, in which AVE values were as follows: servant leadership (0.663), climate for creativity (0.724) and creativity (0.762), whereas CR values were as follows: servant leadership (0.939), climate for creativity (0.929) and creativity (0.966). The results indicated that the AVE and CR values for all the variables were higher than 0.5 and 0.7 , respectively (Fornell and Larcker, 1981). This implies that the conditions of convergent validity were met. Discriminant validity was checked by comparing the square root of the AVE with the correlations between the constructs (Fornell and Larcker, 1981). The results indicate that the AVE square root was higher than the correlation between the corresponding pair of variables, suggesting that the condition of discriminant validity was also met.

\section{Hypotheses testing}

Table 3 shows the values of mean, standard deviations (SDs) and Pearson's correlations. The values of mean and standard deviations for servant leadership were mean $=4.43$ and $\mathrm{SD}=1.5$; climate for creativity: mean $=5.00$ and $\mathrm{SD}=1.55$; creativity: mean $=5.04$ and $\mathrm{SD}=1.52$. Significant correlations were found between servant leadership and climate for creativity $(r=0.668, p=0.000)$, climate for creativity and creativity $(r=0.839, p=0.000)$ and servant leadership and creativity $(r=0.663, p=0.000)$.

A structural equation model (SEM) was built to verify the study hypotheses included servant leadership, creativity, climate for creativity and the control variables. The results of model fit indices indicated that the data showed a good fit with the structural model $\chi^{2}=531.258 ; \mathrm{df}=270 ; p=0.000 ; \mathrm{CFI}=0.955 ; \mathrm{AIC}=641.258 ; \mathrm{TLI}=0.948 ; \mathrm{SRMR}=0.061$; RMSEA $=0.065$ ). The parsimony adjusted measures were PARITO $=0.9, \mathrm{PNFI}=0.821$ and $\mathrm{PCFI}=0.859$. The results indicated that servant leadership was positively and significantly associated with creativity $(\beta=0.185 ; p=0.001)$, servant leadership depicted a positive relationship with climate for creativity $(\beta=0.679 ; p=0.000)$ and climate for creativity was positively associated with creativity $(\beta=0.748 ; p=0.001)$. Thus, the results lend support for $\mathrm{H} 1, \mathrm{H} 2$ and $\mathrm{H} 3$. For the mediation analysis, the results revealed a significant indirect effect of climate for creativity on the association between servant leadership and creativity $(\beta=0.509$; $p=0.000$ ), suggesting that climate for creativity was a significant mediator in the servant leadership-creativity relationship, thus lending support for H4 (see Figure 2).

\section{Discussion and implications}

This paper aimed to test the effect of servant leadership on followers' creativity via the climate for creativity in the hospitality industry. The results demonstrated that servant leadership was positively related to followers' creativity, with and the results were in line with the previous studies (i.e. Liden et al., 2014; Williams et al., 2017; Yoshida et al., 2014) that, although limited, established that a relationship exists between servant leadership and followers' creativity. The results indicated that when followers perceive their leaders as careful and less selfish, they are more likely to feel psychologically safe and show trust toward them (Liden et al., 2015), which succeeds in enhancing problem-solving initiatives and reducing the risks associated with creativity (Yoshida et al., 2014). These results lend a support to the theoretical arguments rooted in social exchange theory (Cropanzano and Mitchell, 2005), which 


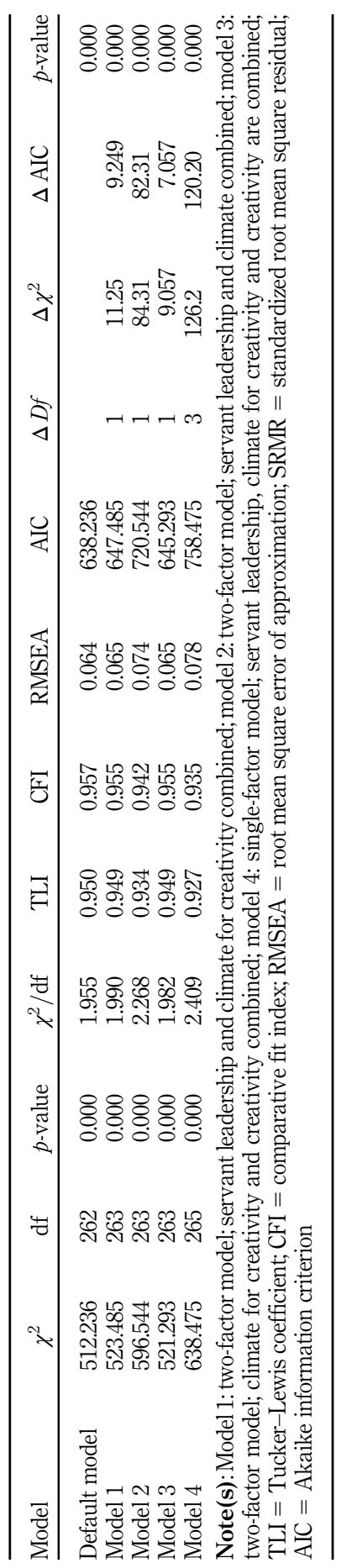

Servant leadership and followers' creativity

85

Table 1

The confirmatory factor analysis and alternate models 


\section{EBHRM 9,1}

\begin{tabular}{|c|c|c|c|c|c|c|}
\hline Construct & Items & S. Loading & $p$-value & $t$-value & AVE & $\mathrm{CR}$ \\
\hline \multirow[t]{7}{*}{$\begin{array}{l}\text { Servant leadership } \\
\text { Liden } \text { et al. (2015) }\end{array}$} & $\begin{array}{l}\text { My leader would not compromise } \\
\text { ethical principles to achieve } \\
\text { success }\end{array}$ & 0.838 & 0.000 & 13.17 & \multirow[t]{7}{*}{0.663} & \multirow[t]{7}{*}{0.939} \\
\hline & $\begin{array}{l}\text { My leader gives me the freedom to } \\
\text { handle difficult situations in the } \\
\text { way that I feel is best }\end{array}$ & 0.867 & 0.000 & 13.83 & & \\
\hline & $\begin{array}{l}\text { My leader puts my best interests } \\
\text { ahead of his/her own }\end{array}$ & 0.679 & 0.000 & 10.53 & & \\
\hline & $\begin{array}{l}\text { My leader emphasizes the } \\
\text { importance of giving back to the } \\
\text { community }\end{array}$ & 0.872 & 0.000 & 13.93 & & \\
\hline & $\begin{array}{l}\text { I would seek help from my leader if } \\
\text { I had a personal problem }\end{array}$ & 0.867 & 0.000 & 13.71 & & \\
\hline & $\begin{array}{l}\text { My leader makes my career } \\
\text { development a priority }\end{array}$ & 0.814 & 0.000 & 12.87 & & \\
\hline & $\begin{array}{l}\text { My leader can tell if something } \\
\text { work-related is going wrong }\end{array}$ & 0.743 & & $\mathrm{~F}$ & & \\
\hline \multirow{5}{*}{$\begin{array}{l}\text { Climate for } \\
\text { creativity Kim and } \\
\text { Yoon (2015) }\end{array}$} & $\begin{array}{l}\text { This hotel publicly recognizes } \\
\text { those who are creative }\end{array}$ & 0.824 & 0.000 & 17.31 & \multirow[t]{5}{*}{0.724} & \multirow[t]{5}{*}{0.929} \\
\hline & $\begin{array}{l}\text { The reward system here } \\
\text { encourages employees' creative } \\
\text { idea development }\end{array}$ & 0.765 & 0.000 & 18.44 & & \\
\hline & $\begin{array}{l}\text { Around here, people are allowed to } \\
\text { try solving the same problems in } \\
\text { different ways }\end{array}$ & 0.827 & 0.000 & 17.46 & & \\
\hline & $\begin{array}{l}\text { This hotel can be described as } \\
\text { flexible and continually adapting to } \\
\text { change }\end{array}$ & 0.930 & 0.000 & 22.80 & & \\
\hline & $\begin{array}{l}\text { There are adequate resources } \\
\text { devoted to innovation in this hotel }\end{array}$ & 0.898 & 0.000 & $\mathrm{~F}$ & & \\
\hline \multirow[t]{9}{*}{$\begin{array}{l}\text { Creativity Tierney } \\
\text { et al. (1999) }\end{array}$} & $\begin{array}{l}\text { I demonstrate originality in higher } \\
\text { work }\end{array}$ & 0.915 & 0.000 & 28.25 & \multirow[t]{9}{*}{0.762} & \multirow[t]{9}{*}{0.966} \\
\hline & $\begin{array}{l}\text { I take risks in terms of producing } \\
\text { new ideas in doing the job }\end{array}$ & 0.941 & 0.000 & 32.30 & & \\
\hline & $\begin{array}{l}\text { I find new uses for existing } \\
\text { methods or equipment }\end{array}$ & 0.962 & 0.000 & $\mathrm{~F}$ & & \\
\hline & $\begin{array}{l}\text { I solve problems that had caused } \\
\text { other difficulty }\end{array}$ & 0.922 & 0.000 & 29.23 & & \\
\hline & $\begin{array}{l}\text { I try out new ideas and approached } \\
\text { problems }\end{array}$ & 0.815 & 0.000 & 19.53 & & \\
\hline & $\begin{array}{l}\text { I identify opportunities for new } \\
\text { products/processes }\end{array}$ & 0.708 & 0.000 & 14.42 & & \\
\hline & $\begin{array}{l}\text { Igenerate novel but operable work- } \\
\text { related ideas }\end{array}$ & 0.840 & 0.000 & 21.18 & & \\
\hline & $\begin{array}{l}\text { I serve as a good role model for } \\
\text { creativity }\end{array}$ & 0.877 & 0.000 & 24.12 & & \\
\hline & I generate ideas revolutionary to & 0.849 & 0.000 & 21.85 & & \\
\hline
\end{tabular}

Table 2.

Standardized loading, average variances extracted and composite reliabilities
Note(s): All loadings were significant at the 0.01 level; F: loading was initially set to 1.00 to fix the scale of the latent variable. All loadings were significant at the 0.01 level; AVE = average variance extracted; $\mathrm{CR}=$ composite reliability

highlights that in a workplace characterized by quality social exchanges between the leader and the follower, followers are more likely to reciprocate the positive behaviors of the servant 
leader with positive work-related outcomes. Therefore, when followers positively perceive their servant leaders, they have the tendency to pay back through creative behaviors.

The results also indicated that servant leadership had a positive relationship with climate for creativity. This finding was in line with that argued by previous research (see Eustace and Martins, 2014), which concluded that the presence of leadership significantly affects organizational climate because leaders have a critical role in redacting the climate within the organization (Cloete, 2011). On the relationship between climate for creativity and followers' creativity, the results indicated that climate for creativity had a positive effect in this context. The results were consistent with the theoretical underpinning founded in the componential theory of creativity, which highlights the significant role of the work environment in supporting creativity (Amabile, 2013; Amabile et al., 1996). Accordingly, a work environment which is characterized by rewarding system recognition, flexibility and availability of resources for creativity would provide the foundation for generating creative behaviors among employees.

This implies that when employees recognize a work environment as flexible, with sufficient resources, rewards for creativity and respect for creative efforts, they are more likely to show creative behaviors. Finally, the results indicated that climate for creativity displays a significant intervening role in the link between servant leadership and followers' creativity.

\begin{tabular}{lccccccccc}
\hline & Mean & SD & 1 & 2 & 3 & 4 & 5 & 6 & 7 \\
\hline Gender & - & 0.486 & 1 & & & & & & \\
Education & 1.65 & 0.840 & -0.062 & 1 & & & & & \\
Age & 2.53 & 0.842 & -0.060 & $0.199^{* * *}$ & 1 & & & & \\
$\begin{array}{l}\text { Experience } \\
\begin{array}{l}\text { Servant } \\
\text { leadership }\end{array}\end{array}$ & 3.13 & 1.22 & -0.017 & $0.209^{* *}$ & $0.809^{* *}$ & 1 & & & \\
$\begin{array}{l}\text { Climate for } \\
\text { creativity }\end{array}$ & 5.43 & 1.59 & 0.038 & -0.044 & 0.073 & 00.049 & $(0.814)$ & & \\
Creativity & 5.00 & 1.55 & -0.063 & 0.072 & $0.165^{*}$ & $0.137^{*}$ & $0.668^{* *}$ & $(0.851)$ & \\
& 5.04 & 1.52 & -0.043 & 0.067 & $0.223^{* *}$ & $0.168^{*}$ & $0.663^{* *}$ & $0.839^{* *}$ & $(0.873)$
\end{tabular}

Note(s): **correlation is significant at the 0.01 level ( two-tailed); *correlation is significant at the 0.05 level (two-tailed); $N 232$

\section{Servant leadership and followers' creativity}

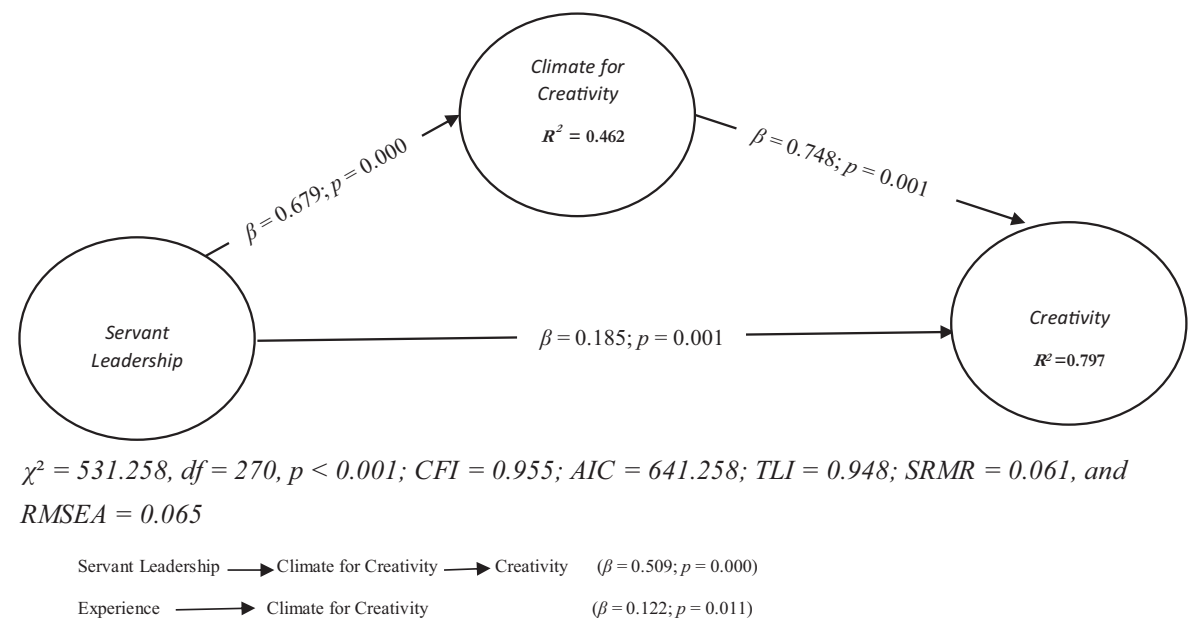

Table 3. Mean, standard deviations, correlations and square root of average variances extracted in diagonal 
EBHRM

9,1

88

This was also in line with previous studies, which found that organizational climate significantly mediates the link between leadership and innovation outcomes (Hassi, 2019; Hosseini et al., 2003; Sethibe and Steyn, 2018). The implication is that the servant leadershipcreativity relationship is not straightforward and climate for creativity plays an intervening mechanism.

Theoretically, this study contributes to servant leadership research in several ways. First, in responding to the scholarly calls made to advance the servant leadership body of knowledge - still in its maturity stage (Eva et al., 2019). Even more crucially, Karatepe et al. (2019) called for the need to further examine the mechanism through which servant leadership affects individual/organizational outcomes. Hence, the findings provide an important understanding of how servant leadership affects creativity through the intervening mechanism of climate for creativity - a variable that has not been investigated before in servant leadership-creativity research. Second, the study investigates the impact of servant leadership on creativity in the hospitality industry, within which little is known about how servant leaders' behaviors affect employees' behaviors (Ling et al., 2016). Finally, as the majority of servant leadership research studies have been conducted in Western countries (Parris and Peachey, 2013), the study contributes to servant leadership literature pertaining to the nature of the relationship between servant leaders' behaviors and creativity by focusing exclusively on Middle Eastern data.

From a practical standpoint, organizations, especially hotels, that are concerned with seeking timely and efficient responses to a competitive market environment should be focused on the promotion of creativity among employees. The key requirement for hotel management is the crucial necessity of promoting a supportive working climate through which followers perceive that they are empowered and receive individualized care, rewards and recognition for creative behaviors. As the findings provide insight into how servant leadership can be used to foster a creative environment and, thus, help to increase followers' engagement in creative behaviors, hotel managers are recommended to select, train and develop servant leaders for the purpose of promoting and creating a climate for creative behaviors. Therefore, utilizing training programs that strengthen the competencies of the servant leader, the success of servant leadership in promoting a climate for creativity can be advanced further. Finally, to foster followers' creativity, hotel managers need to provide the proper resources, encouragement and support for followers in generating novel solutions and creative ideas.

\section{Limitations and future research}

The study's findings should be carefully interpreted due to the study's limitations. First, as the research design is a cross-sectional one, the research's findings cannot be interpreted in terms of causality. Hence, longitudinal studies are required to examine the effects of the variables in the hypothesized model over time. Second, the data for the research study were collected from Palestine's hotels sector, which might limit the generalizability of the findings to other sectors. Therefore, future research might consider replicating the findings in other contexts, including business, governmental and nongovernmental organizations. Third, the research model includes examining one intervening mechanism (climate for creativity) in the servant leadership-creativity relationship. Future studies should consider other mediating factors such as climate for innovation, learning-oriented organizational, justice and trust climates and climate for change. Fourth, the data were collected from self-reported measures, which could introduce a common bias. Although the statistical remedies conducted indicated that common bias variance did not affect the study, future research is recommended to collect data via multiple sources to ensure a higher level of objectivity and reduce any potential bias. Fifth, the study examined the hypothesized model at an individual level. Thus, future 
research might consider examining the effect of servant leadership on team-level creativity, considering the role played by organizational climate. This can be achieved via a multilevel model to provide more insights into the effect of servant leadership on these outcomes (Yoshida et al., 2014). Moreover, future research should consider including other leadership styles, such as ethical, empowering or inclusive leadership, in order to validate the variance counted by servant leadership in followers' creativity.

\section{References}

Agars, M.D., Kaufman, J.C., Deane, A. and Smith, B. (2012), "Fostering individual creativity through organizational context: a review of recent research and recommendations for organizational leaders", in Mumford, M.D. (Ed.), Handbook of Organizational Creativity, Academic Press, San Diego, pp. 271-291.

Amabile, T.M. (1988), "A model of creativity and innovation in organizations", Research in Organizational Behavior, Vol. 10 No. 1, pp. 123-167.

Amabile, T.M. (1997), "Motivating creativity in organizations: on doing what you love and loving what you do", California Management Review, Vol. 40 No. 1, pp. 39-58.

Amabile, T.M. and Gryskiewicz, N.D. (1989), "The creative environment scales: work environment inventory", Creativity Research Journal, Vol. 2 No. 4, pp. 231-253.

Amabile, T.A. and Khaire, M. (2008), "Creativity and the role of the leader", Harvard Business Review, Vol. 86 No. 10, pp. 100-109.

Amabile, T.M. and Mueller, J. (2008), "Assessing creativity and its antecedents: An exploration of the componential theory of creativity", in Zhou, J. and Shalley, C.E. (Eds), Handbook of Organizational Creativity, Madison Ave, Taylor and Francis Group, New York, NY, pp. 33-64.

Amabile, T.M., Conti, R., Coon, H., Lazenby, J. and Herron, M. (1996), "Assessing the work environment for creativity", Academy of Management Journal, Vol. 39 No. 5, pp. 1154-1184.

Amabile, T.M. (2013), "Componential theory of creativity", in Kessler, E.H. (Ed.), Encyclopedia of Management Theory, SAGE Publications, Thousand Oaks, CA, pp. 135-140.

Anderson, J.C. and Gerbing, D.W. (1988), "Structural equation modeling in practice: a review and recommended two-step approach", Psychological Bulletin, Vol. 103 No. 3, pp. 411-423.

Anderson, N.R. and West, M.A. (1998), "Measuring climate for work group innovation: development and validation of the team climate inventory", Journal of Organizational Behavior, Vol. 19 No. 3, pp. 235-258.

Anderson, N., De Dreu, C.K.W. and Nijstad, B.A. (2004), "The routinization of innovation research: a constructively critical review of the state-of-the-science", Journal of Organizational Behavior, Vol. 25 No. 2, pp. 147-173.

Avolio, B.J., Walumbwa, F.O. and Weber, T.J. (2009), "Leadership: current theories, research, and future directions", Annual Review of Psychology, Vol. 60 No. 1, pp. 421-449.

Bavik, A. (2020), "A systematic review of the servant leadership literature in management and hospitality", International Journal of Contemporary Hospitality Management, Vol. 32 No. 1, pp. 347-382.

Bavik, A., Bavik, Y.L. and Tang, P.M. (2017), "Servant leadership, employee job crafting, and citizenship behaviors: a cross-level investigation”, Cornell Hospitality Quarterly, Vol. 58 No. 4, pp. 364-373.

Bentler, P.M. and Bonett, D.G. (1980), "Significance tests and goodness of fit in the analysis of covariance structures", Psychological Bulletin, Vol. 88 No. 3, pp. 588-606.

Brislin, R.W. (1986), "The wording and translation of research instruments", in Lonner, W.J. and Berry, J.W. (Eds), Field Methods in Cross-Cultural Research, Sage Publications, Thousand Oaks, CA, pp. 137-164.

Burton, R.M., Lauridsen, J. and Obel, B. (2004), "The impact of organizational climate and strategic fit on firm performance", Human Resource Management, Vol. 43 No. 1, pp. 67-82. 
EBHRM 9,1

Carmeli, A., Gelbard, R. and Reiter-Palmon, R. (2013), "Leadership, creative problem-solving capacity, and creative performance: the importance of knowledge sharing", Human Resource Management, Vol. 52 No. 1, pp. 95-121.

Chiniara, M. and Bentein, K. (2016), "Linking servant leadership to individual performance: differentiating the mediating role of autonomy, competence and relatedness need satisfaction", The Leadership Quarterly, Vol. 27 No. 1, pp. 124-141.

Choi, B.K., Moon, H.K. and Ko, W. (2016), “An organization's ethical climate, innovation, and performance: effects of support for innovation and performance evaluation”, Management Decision, Vol. 51 No. 6, pp. 1250-1275.

Churchill, G. and Iacobucci, D. (2002), Marketing Research: Methodological Foundations, South-Western, London.

Cloete, M. (2011), The Relationship between Leadership Styles and Organisational Climat, University of South Africa Pretoria, Pretoria.

Conway, J.M. and Lance, C.E. (2010), "What reviewers should expect from authors regarding common method bias in organizational research", Journal of Business and Psychology, Vol. 25 No. 3, pp. 325-334.

Cropanzano, R. and Mitchell, M. (2005), "Social exchange theory: an interdisciplinary review”, Journal of Management, Vol. 31 No. 6, pp. 874-900.

Ekvall, G. (1996), “Organizational climate for creativity and innovation”, European Journal of Work and Organizational Psychology, Vol. 5 No. 1, pp. 105-123.

Ensor, J., Pirrie, A. and Band, C. (2006), "Creativity work environment: do UK advertising agencies have one?", European Journal of Innovation Management, Vol. 9 No. 3, pp. 258-268.

Eustace, A. and Martins, N. (2014), "The role of leadership in shaping organisational climate: an example from the fast moving consumer goods industry", SA Journal of Industrial Psychology, Vol. 40 No. 1, pp. 1-14.

Eva, N., Robin, M., Sendjaya, S., van Dierendonck, D. and Liden, R.C. (2019), "Servant leadership: a systematic review and call for future research", The Leadership Quarterly, Vol. 30 No. 1, pp. 111-132.

Feist, G.J. (1998), “A meta-analysis of personality in scientific and artistic creativity”, Personality and Social Psychology Review, Vol. 2 No. 4, pp. 290-309.

Fischer, C., Malycha, C.P. and Schafmann, E. (2019), "The influence of intrinsic motivation and synergistic extrinsic motivators on creativity and innovation”, Frontiers in Psychology, Vol. 10 February, pp. 1-15.

Fornell, C. and Larcker, D.F. (1981), "Evaluating structural equation models with unobservable variables and measurement error”, Journal of Marketing Research, Vol. 18 No. 1, pp. 39-50.

Graham, J.W. (1991), "Servant-leadership in organizations: inspirational and moral", The Leadership Quarterly, Vol. 2 No. 2, pp. 105-119.

Greenleaf, R.K. (1970), "The servant as leader”, in Zimmerli, W.C., Holzinger, M. and Richter, K. (Eds), Corporate Ethics and Corporate Governance, The Robert K. Greenleaf Center, Indianapolis. doi: 10.1007/978-3-540-70818-6_6.

Hamel, G. and Valikangas, L. (2003), “The quest for resilience”, Harvard Business Review, Vol. 81 No. 9, pp. 52-63.

Hassi, A. (2019), "Empowering leadership and management innovation in the hospitality industry context: the mediating role of climate for creativity", International Journal of Contemporary Hospitality Management, Vol. 31 No. 4, pp. 1785-1800.

Hoch, J.E., Bommer, W.H., Dulebohn, J.H. and Wu, D. (2018), "Do ethical, authentic, and servant leadership explain variance above and beyond transformational leadership? A meta-analysis", Journal of Management, Vol. 44 No. 2, pp. 501-529. 
Hosseini, H.K., Azar, A. and Rostamy, A.A.A. (2003), "The intervening role of innovative climate: a mtudy of middle managers in manufacturing organizations in Iran”, Public Organization Review, Vol. 3 No. 2, pp. 151-170.

Huning, T.M., Hurt, K.J. and Frieder, R.E. (2020), "The effect of servant leadership, perceived organizational support, job satisfaction and job embeddedness on turnover intentions: an empirical investigation", Evidence-Based HRM, Vol. 8 No. 2, pp. 177-194.

Hunter, E.M., Neubert, M.J., Perry, S.J., Witt, L.A., Penney, L.M. and Weinberger, E. (2013), "Servant leaders inspire servant followers: antecedents and outcomes for employees and the organization”, The Leadership Quarterly, Vol. 24 No. 2, pp. 316-331.

Karatepe, O.M., Ozturk, A. and Kim, T.T. (2019), "Servant leadership, organisational trust, and bank employee outcomes", The Service Industries Journal, Vol. 39 No. 2, pp. 86-108.

Kaya, B. and Karatepe, O.M. (2020), "Does servant leadership better explain work engagement, career satisfaction and adaptive performance than authentic leadership?", International Journal of Contemporary Hospitality Management, Vol. 32 No. 6, pp. 2075-2095.

Kim, S. and Yoon, G. (2015), "An innovation-driven culture in local government: do senior manager's transformational leadership and the climate for creativity matter?", Public Personnel Management, Vol. 44 No. 2, pp. 147-168.

Ko, W.H. and Kang, H.Y. (2019), "Effect of leadership style and organizational climate on employees' food safety and hygiene behaviors in the institutional food service of schools", Food Science and Nutrition, Vol. 7 No. 6, pp. 2131-2143.

Langhof, J.G. and Güldenberg, S. (2020), "Servant leadership: a systematic literature review-toward a model of antecedents and outcomes", German Journal of Human Resource Management, Vol. 28 Nos 1-2, pp. 52-72.

Lapointe, É. and Vandenberghe, C. (2018), "Examination of the relationships between servant leadership, organizational commitment, and voice and antisocial behaviors", Journal of Business Ethics, Vol. 148 No. 1, pp. 99-115.

Lee, J., Kim, S., Lee, J. and Moon, S. (2019), "Enhancing employee creativity for a sustainable competitive advantage through perceived human resource management practices and trust in management", Sustainability, Vol. 11 No. 8, p. 2305.

Liden, R.C., Wayne, S.J., Zhao, H. and Henderson, D. (2008), "Servant leadership: development of a multidimensional measure and multi-level assessment", Leadership Quarterly, Vol. 19 No. 2, pp. 161-177.

Liden, R.C., Wayne, S.J., Liao, C. and Meuser, J.D. (2014), "Servant leadership and serving culture: influence on individual and unit performance", Academy of Management Journal, Vol. 57 No. 5 , pp. 1434-1452.

Liden, R.C., Wayne, S.J., Meuser, J.D., Hu, J., Wu, J. and Liao, C. (2015), "Servant leadership: validation of a short form of the SL-28", Leadership Quarterly, Vol. 26 No. 2, pp. 254-269.

Ling, Q., Lin, M. and Wu, X. (2016), "The trickle-down effect of servant leadership on frontline employee service behaviors and performance: a multilevel study of Chinese hotels", Tourism Management, Vol. 52, pp. 341-368.

Ling, Q., Liu, F. and Wu, X. (2017), "Servant versus authentic leadership: assessing effectiveness in China's hospitality industry", Cornell Hospitality Quarterly, Vol. 58 No. 1, pp. 53-68.

Manning, M.L., Davidson, M. and Manning, R.L. (2005), "Measuring tourism and hospitality employee workplace perceptions", International Journal of Hospitality Management, Vol. 24 No. 1, pp. $75-90$.

Minh-Duc, L. and Huu-Lam, N. (2019), "Transformational leadership, customer citizenship behavior, employee intrinsic motivation, and employee creativity", Journal of Asian Business and Economic Studies, Vol. 26 No. 2, pp. 286-300.

Mohamed, L.M. (2016), "Assessing the effects of transformational leadership: a study on Egyptian hotel employees", Journal of Hospitality and Tourism Management, Vol. 27, pp. 49-59. 
EBHRM

9,1

92

Neubert, M.J., Kacmar, K.M., Carlson, D.S., Chonko, L.B. and Roberts, J.A. (2008), "Regulatory focus as a mediator of the influence of initiating structure and servant leadership on employee behavior", Journal of Applied Psychology, Vol. 93 No. 6, pp. 1220-1233.

Neubert, M.J., Hunter, E.M. and Tolentino, R.C. (2016), “A servant leader and their stakeholders: when does organizational structure enhance a leader's influence?”, The Leadership Quarterly, Vol. 27 No. 6, pp. 896-910.

Newman, A., Schwarz, G., Cooper, B. and Sendjaya, S. (2017), "How servant leadership influences organizational citizenship behavior: the roles of LMX, empowerment, and proactive personality", Journal of Business Ethics, Vol. 145 No. 1, pp. 49-62.

Oldham, G.R. and Cummings, A. (1996), "Employee creativity: personal and contextual factors at Work", Academy of Management Journal, Vol. 39 No. 3, pp. 607-634.

Parris, D.L. and Peachey, J.W. (2013), "A systematic literature review of servant leadership theory in organizational contexts", Journal of Business Ethics, Vol. 113 No. 3, pp. 377-393.

Paulsen, N., Callan, V.J., Ayoko, O. and Saunders, D. (2013), "Transformational leadership and innovation in an RandD organization experiencing major change", Journal of Organizational Change Management, Vol. 26 No. 3, pp. 595-610.

Porzse, G., Takacs, S., Csedo, Z., Berta, Z., Sara, Z. and Fejes, J. (2012), "The impact of creative organizational climate on the innovation activity of medical devices manufacturing firms in Hungary", European Journal of Business and Management, Vol. 4 No. 13, pp. 1-11.

Podsakoff, P.M., MacKenzie, S.B., Lee, J.Y. and Podsakoff, N.P. (2003), "Common method biases in behavioral research: a critical review of the literature and recommended remedies", Journal of Applied Psychology, Vol. 88 No. 5, pp. 879-903.

Preacher, K.J. and Hayes, A.F. (2008), "Asymptotic and resampling strategies for assessing and comparing indirect effects in multiple mediator models", Behavior Research Methods, Vol. 40 No. 3, pp. 879-891.

Russell, R.F. and Stone, G.A. (2002), "A review of servant leadership attributes: developing a practical model", Leadership and Organization Development Journal, Vol. 23 No. 3, pp. 145-157.

Sethibe, T. and Steyn, R. (2018), "The mediating effect of organizational climate on the relationship between leadership styles and their components on innovative behaviour", Journal of Entrepreneurship and Innovation in Emerging Economies, Vol. 4 No. 1, pp. 22-32.

Shalley, C.E. and Gilson, L.L. (2004), "What leaders need to know: a review of social and contextual factors that can foster or hinder creativity", The Leadership Quarterly, Vol. 15 No. 1, pp. 33-53.

Shalley, C.E., Zhou, J. and Oldham, G.R. (2004), "The effects of personal and contextual characteristics on creativity: where should we go from here?", Journal of Management, Vol. 30 No. 6, pp. 933-958.

Stone, G.A., Russell, R.F. and Patterson, K. (2004), "Transformational versus servant leadership: a difference in leader focus", Leadership and Organization Development Journal, Vol. 25 No. 4, pp. 349-361.

Tang, G., Kwan, H.K., Zhang, D. and Zhu, Z. (2016), "Work-family effects of servant leadership: the roles of emotional exhaustion and personal learning", Journal of Business Ethics, Vol. 137 No. 2, pp. 285-297.

Tesluk, P.E., Farr, J.L. and Klein, S.R. (1997), "Influences of organizational culture and climate on individual creativity", The Journal of Creative Behavior, Vol. 31 No. 1, pp. 27-41.

Thao, N.P.H. and Kang, S.W. (2018), "Servant leadership and follower creativity via competence: a moderated mediation role of perceived organisational support", Journal of Pacific Rim Psychology, Vol. 12, p. e32.

Tierney, P., Farmer, S.M. and Graen, G.B. (1999), "An examination of leadership and employee creativity: the relevance of traits and relationships", Personnel Psychology, Vol. 52 No. 3, pp. $591-620$. 
Van der Vegt, G.S., Van de Vliert, E. and Huang, X. (2005), "Location-level links between diversity and innovative climate depend on national power distance", Academy of Management Journal, Vol. 48 No. 6, pp. 1171-1182.

Van Dierendonck, D. (2011), "Servant leadership: a review and synthesis", Journal of Management, Vol. 37 No. 4, pp. 1228-1261.

Van Dierendonck, D. and Rook, L. (2010), van Dierendonck, D. and Patterson, K. (Eds), Enhancing Innovation and Creativity through Servant Leadership BT - Servant Leadership: Developments in Theory and Research, Palgrave Macmillan UK, London, pp. 155-165.

Walumbwa, F.O., Hartnell, C.A. and Oke, A. (2010), "Servant leadership, procedural justice climate, service climate, employee attitudes, and organizational citizenship behavior: a cross-level investigation”, Journal of Applied Psychology, Vol. 95 No. 3, pp. 517-529.

Walumbwa, F.O., Muchiri, M.K., Misati, E., Wu, C. and Meiliani, M. (2018), "Inspired to perform: a multilevel investigation of antecedents and consequences of thriving at work", Journal of Organizational Behavior, Vol. 39 No. 3, pp. 249-261.

Weeks, R. (2008), "Nurturing a culture and climate of resilence to navigate the whitewaters of the South African dual economy", Journal of Contemporary Management, Vol. 5 No. 1, pp. 123-136.

West, M.A., Borrill, C.S., Dawson, J.F., Brodbeck, F., Shapiro, D.L. and Haward, B. (2003), "Leadership clarity and team innovation in health care", Leadership Quarterly, Vol. 14 Nos 4-5, pp. 393-410.

West, M.A. and Sacramento, C.A. (2012), "Creativity and innovation: the role of team and organizational climate", in M.D.B.T.H. of Mumford, O.C. (Ed.), Handbook of Organizational Creativity, Academic Press, San Diego, pp. 359-385.

Williams, W.A., Jr, Brandon, R.-S., Hayek, M., Haden, S.P. and Atinc, G. (2017), "Servant leadership and followership creativity: the influence of workplace spirituality and political skill", Leadership and Organization Development Journal, Vol. 38 No. 2, pp. 178-193.

Woodman, R.W., Sawyer, J.E. and Griffin, R.W. (1993), “Toward a theory of organizational creativity”, Academy of Management Review, Vol. 18 No. 2, pp. 293-321.

Wu, L.-Z., Tse, E.C.-Y., Fu, P., Kwan, H.K. and Liu, J. (2013), "The impact of servant leadership on hotel employees' 'servant behavior”, Cornell Hospitality Quarterly, Vol. 54 No. 4, pp. 383-395.

Yang, J., Liu, H. and Gu, J. (2017), "A multi-level study of servant leadership on creativity: the roles of self-efficacy and power distance”, Leadership and Organization Development Journal, Vol. 38 No. 5, pp. 610-629.

Yeh-Yun Lin, C. and Liu, F.C. (2012), "A cross-level analysis of organizational creativity climate and perceived innovation: the mediating effect of work motivation", European Journal of Innovation Management, Vol. 15 No. 1, pp. 55-76.

Yoshida, D.T., Sendjaya, S., Hirst, G. and Cooper, B. (2014), "Does servant leadership foster creativity and innovation? A multi-level mediation study of identification and prototypicality", Journal of Business Research, Vol. 67 No. 7, pp. 1395-1404.

Zhou, J. and Shalley, C.E. (2003), "Research on employee creativity: a critical review and directions for future research", Research in Personnel and Human Resources Management, Vol. 22, pp. 165-217, Emerald Group Publishing, Bingley, doi: 10.1016/S0742-7301(03)22004-1.

Zoghbi-Manrique-de-Lara, P. and Ruiz-Palomino, P. (2019), "How servant leadership creates and accumulates social capital personally owned in hotel firms", International Journal of Contemporary Hospitality Management, Vol. 31 No. 8, pp. 3192-3321.

\section{About the author}

Dr Mohammed Aboramadan received his $\mathrm{PhD}$ in economics and management (major: management) from the University of Pavia, Italy. Currently, Dr. Aboramadan works as a postdoctoral research fellow at the department of economics, management and statistics with areas focused on human resource management (HRM), leadership, employee and organizational performance. Dr Aboramadan has published at the International Journal of Contemporary Hospitality Management, International 
EBHRM

9,1

94

Journal of Voluntary and Nonprofit Organizations, Journal of Management Development, International Journal of Organizational Analysis, International Journal of Educational Management, Journal of Higher Education Policy and Management, International Journal of Public Administration and Journal for Global Business Advancement. Mohammed Aboramadan can be contacted at: mohammed.aboramadan@unimib.it

For instructions on how to order reprints of this article, please visit our website: www.emeraldgrouppublishing.com/licensing/reprints.htm Or contact us for further details: permissions@emeraldinsight.com 